\title{
A role for phosphorylation by casein kinase II in modulating Antennapedia activity in Drosophila
}

\author{
Leah Jaffe, Hyung-Don Ryoo, and Richard S. Mann ${ }^{1}$ \\ Department of Biochemistry and Molecular Biophysics, Columbia University College of Physicians and Surgeons, New \\ York, NY 10032 USA
}

\begin{abstract}
We present evidence that the in vivo activity of the HOX protein Antennapedia (ANTP) is modified because of phosphorylation by the serine/threonine kinase casein kinase II (CKII). Using an in vivo assay a form of ANTP that has alanine substitutions at its CKII target sites has, in addition to wild-type ANTP functions, the ability to alter severely thoracic and abdominal development. The novel functions of this protein suggest that this form of ANTP is not suppressed phenotypically by the more posterior homeotic proteins. In contrast, the in vivo activity of a form of ANTP that contains acidic amino acid substitutions at its CKII target sites, thereby mimicking a constitutively phosphorylated ANTP protein, is greatly reduced. This hypoactive form of ANTP, but not the alanine-substituted form, is also reduced in its ability to bind to DNA cooperatively with the homeodomain protein Extradenticle. Our results suggest that phosphorylation of ANTP by CKII is important for preventing inappropriate activities of this homeotic protein during embryogenesis.
\end{abstract}

[Key Words: Homeotic protein (HOX); Antennapedia; phosphorylation; casein kinase II; extradenticle; phenotypic suppression]

Received March 4, 1997; revised version accepted March 28, 1997.

The unique identities of the segments of Drosophila melanogaster are determined by the homeotic (HOX) genes, which select particular developmental fates in segment primordia and maintain these fates throughout development (Lewis 1978). It has been proposed that the homeotic genes establish segment identities by regulating the expression of downstream target genes (GarciaBellido 1975). This suggestion is supported by the fact that all homeotic genes encode proteins that contain a homeodomain, which functions, at least in part, as a DNA-binding domain (Desplan et al. 1985; Hoey et al. 1988). Thus, HOX proteins presumably achieve their affect on anteroposterior axial identities by activation and repression of specific sets of downstream genes (Botas 1993!.

Curiously, HOX proteins are able to generate homeotic transformations in only a subset of metameres, even when expressed ubiquitously. In general, for any specific HOX protein only those segments anterior to its normal expression domain have the potential to be transformed by that HOX protein (Gibson and Gehring 1988; Gonzalez-Reyes et al. 1990; Mann and Hogness 1990; Chisaka et al. 1992; Lamka et al. 1992; Lufkin et al. 1992). Homeotic genes that are expressed more posteriorly in the body appear to suppress functionally the more ante-

${ }^{1}$ Corresponding author.

E-MAIL rsm10@columbia.edu; FAX (212) 305-7924. riorly expressed homeotic genes. For example, in ectopic expression experiments no known form of the HOX protein Antennapedia (ANTP) has ever disrupted the normal cuticular pattern posterior to the first thoracic segment, despite the large number of variants that have been studied (Gibson and Gehring 1988; Gibson et al. 1990; Chan and Mann 1993). This phenomenon has been termed phenotypic suppression in Drosophila and posterior prevalence in vertebrates (Gonzalez-Reyes and Morata 1990; Duboule 1991). The functional silencing of one homeotic product by another must occur post-transcriptionally because in many of these experiments the suppressed protein is expressed ubiquitously through a heterologous promoter. One possibility is that phenotypic expression is attributable to a competition for DNA-binding sites by different HOX proteins /Gibson and Gehring 1988; Lamka et al. 1992).

Several lines of evidence suggest that the functional specificity of HOX proteins cannot be attributable to differences in their DNA-binding properties alone. HOX proteins have similar homeodomains with nearly identical recognition helices (Burglin 1994) and are able to bind similar DNA sequences in vitro (Desplan et al. 1988; Ekker et al. 1994). Moreover, some of the specific residues implicated in HOX specificity are more likely to contact other proteins rather than DNA (Lin and McGinnis 1992; Chan and Mann 1993; Zeng et al. 1993). Thus, target gene specificity may occur as a result of protein- 
protein interactions in addition to homeodomain-DNA interactions. Consistent with these arguments, the homeodomain proteins encoded by the Drosophila extradenticle gene and mammalian $p b x$ genes bind cooperatively to DNA with HOX proteins, thereby increasing their DNA-binding specificities (for review, see Mann and Chan 1996).

To characterize additional cofactors or modifiers of the HOX proteins we used the yeast two-hybrid method (Chien et al. 1991) to identify proteins that interact with ANTP. One of these ANTP-interacting proteins is the catalytic subunit of the serine (Ser)/threonine (Thr) kinase casein kinase II (CKII). Unlike wild-type ANTP, a form of ANTP that is no longer a substrate for CKII in vitro has novel functions in vivo. In some instances this mutant form of ANTP is not suppressed phenotypically by the posterior HOX genes. Thus, our results suggest that phosphorylation by CKII modifies ANTP function in vivo.

\section{Results}

The yeast two-hybrid system (Chien et al. 1991) was used to identify ANTP-interacting proteins. A portion of ANTP that includes the homeodomain and carboxy-terminal tail, regions known to be important for ANTP. specific functions in vivo (Gibson et al. 1990; Chan and Mann 1993) was fused to the Gal4 DNA-binding domain (GDB-ANTP) and used as the bait (Fig. 1A). Approximately 750,000 yeast colonies expressing GDB-ANTP and Drosophila cDNAs fused to the Gal4 activation domain (GAD-cDNA) were examined for $\beta$-galactosidase activity using a filter assay. Five independent GADcDNA fusions, isolated from one to four times, were shown to interact specifically with GDB-ANTP, but not a negative control fusion GDB-SNFI (data not shown). One ANTP interactor that was isolated twice in the screen was a portion of the catalytic $(\alpha)$ subunit of the Ser/Thr kinase CKII (Table 1) (Saxena et al. 1987). This
Table 1. Yeast two-hybrid interaction data

\begin{tabular}{lll}
\hline Yeast strain $^{\mathrm{a}}$ & \multicolumn{1}{c}{ pGAD } & pGAD-CKII \\
\hline Y.ANTP & white & blue \\
Y.ANTP $^{(3,4) \mathrm{A}}$ & white & white \\
Y.UBX $^{\mathrm{b}}$ & light blue & light blue \\
Y153 & white & white \\
\hline
\end{tabular}

a.ANTP, Y.ANTP ${ }^{[3,4] \mathrm{A}}$, and Y.UBX refer to the yeast strain Y153 transformed with plasmids that express the GAL4 DNAbinding domain fused to the homeodomain and carboxyl terminus of Antp, Antp ${ }^{[3,4] A}$, and $U b x$, respectively.

bThe GAL4 DNA-binding domain- $U b x$ fusion weakly activates transcription in yeast on its own. Therefore, liquid $\beta$-galactosidase assays were used to confirm that the level of activation was not changed by pGAD-CKII $\alpha$.

fragment of CKII did not interact with the homeodomain and carboxy-terminal tail of Ultrabithorax (UBX) in the two-hybrid assay (Table 1). The portion of CKII present in both clones was the carboxy-terminal 176 amino acids of the $\alpha$ subunit, which includes approximately half of the highly conserved core present in most Ser/Thr kinases (Saxena et al. 1987). On the basis of the crystal structures of related kinases (Taylor and Radzio-Andzelm 1994) this portion of CKII includes the binding pocket for a peptide inhibitor, and therefore contains a significant part of the substrate binding site (Knighton et al. 1991a,b).

\section{ANTP ${ }^{[1,2,3,4] A}$ has novel functions in vivo}

Antennapedia contains four putative CKII target sites having the consensus sequence S/T-X-X-D/E (Marchiori et al. 1988). Sites 1 and 2 are found in the amino-terminal portion of the protein, whereas sites 3 and 4 are clustered and close to the homeodomain in the carboxyl tail (Fig. 1A). The ANTP fragment used in the yeast two-hybrid screen included sites 3 and 4 . These sites are important
Figure 1. (A) Diagram (top) of ANTP showing the positions of the putative CKII sites ( 1 to 4 ). The homeodomain is shown as a speckled box and position $50(\mathrm{Q})$ is indicated. The portion of ANTP used in the two-hybrid screen is indicated by the black bar. The sequences of the putative CKII sites in wild-type ANTP and the various mutant forms are shown below; amino acids that were mutagenized are shown in larger type. Only changes from the wildtype sequence are shown. The amino acid numbers of the Ser (S) or Thr $(\mathrm{T})$ for sites 1 to 4 are $35,84,358$, and 364 , respectively. $(B-D)$ ANTP protein detected in 6 to 9-hr wild-type (B), HS:Antp (C), and $H S: A n t p^{[1,2,3,4] A}(D)$ embryos, respectively, $2.5 \mathrm{hr}$ postheat shock. Similar levels of ANTP and ANTP ${ }^{[1,2,3,4] \mathrm{A}}$ were also observed $7.5 \mathrm{hr}$ postheat shock (not shown). ANTP staining in $B, C$, and $D$ is nuclear. Embryos expressing $\operatorname{ANTP}^{[1,2,3,4] \mathrm{E}}$ ubiquitously showed a staining pattern indistinguishable from $C$ or $D$ (not shown). (PS4) Parasegment 4 .
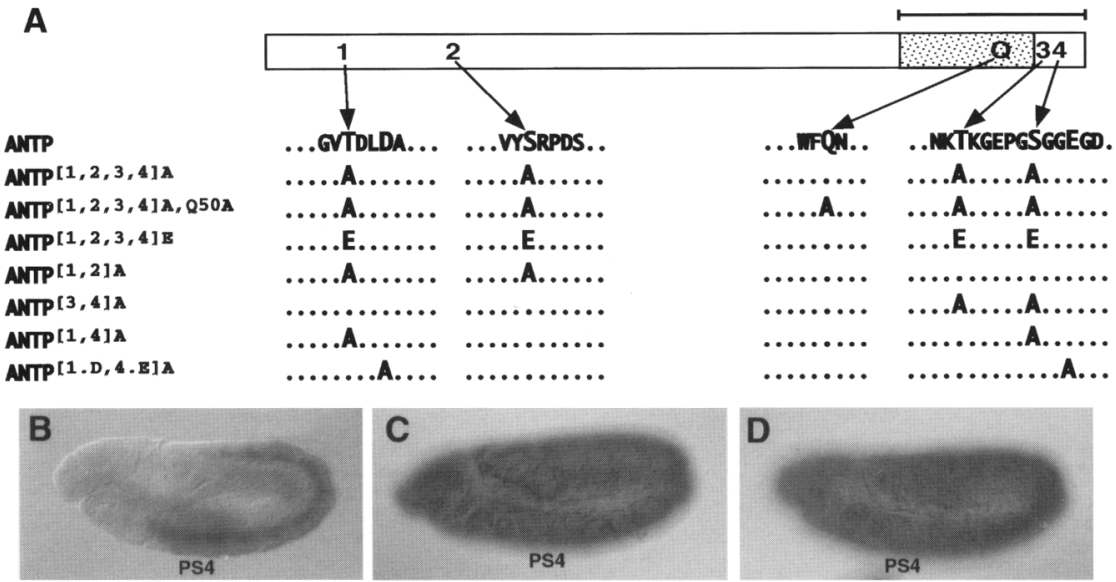
for the interaction in yeast because substituting alanine (Ala) for Ser or Thr at sites 3 and 4 abolished the twohybrid interaction (Table 1). By sequence, sites 1 and 4 are better CKII sites than sites 2 and 3 because they contain additional acidic residues close to Ser or Thr and because sites 2 and 3 both contain nearby basic residues (Fig. 1A).

CKII is present ubiquitously throughout embryogenesis (M. Abu-Shaar and R.S. Mann, data not shown) and therefore, has the potential to phosphorylate ANTP in vivo. To test the significance of the ANTP-CKII interaction all four sites were mutated such that each Ser or Thr residue was substituted with an Ala. The normal and mutant Antp cDNAs (Fig. 1A) were cloned into a P-element vector under the control of the $h s p 70$ promoter to generate $H S: A n t p$ and $H S: A n t p^{[1,2,3,4] A}$, respectively. Each of these elements was introduced into the germ line of flies and at least two transformants for each construct were analyzed. Ubiquitous expression of these proteins was induced by applying a single $45-\mathrm{min} 37^{\circ} \mathrm{C}$ heat shock to embryos aged 3-6 hr. Ubiquitous nuclear expression was confirmed by staining embryos with an ANTP-specific antibody 2.5 and $7.5 \mathrm{hr}$ after the heat shock (Fig. 1C,D; data not shown). The levels of ANTP and ANTP ${ }^{[1,2,3,4] A}$ were similar to the level of ANTP protein normally detected in parasegment 4 (PS4) (Fig. 1B-D). Furthermore, ANTP and ANTP ${ }^{1,2,3,4] A}$ showed similar levels of staining, even $7.5 \mathrm{hr}$ after the heat shock. Thus, the stabilities of these two proteins in vivo are comparable. Segmental transformations induced by ubiquitous expression of these proteins were analyzed by examining the cuticles secreted $\sim 20-25 \mathrm{hr}$ after the heat shock.

Each thoracic and abdominal segment of a wild-type cuticle can be recognized by the size and shape of its denticle belt, which contains small, triangular hairs called denticles. The head segments, which are involuted inside the anterior end of the embryo, have several well-defined structures. In addition, the first thoracic segment (T1) has a patch of denticles known as the $T 1$ beard and each thoracic segment has a pair of sensory structures known as Keilin's organs (Fig. 2A). [See LohsSchardin et al. (1979) and Wieschaus and Nusslein-Volhard (1986) for a detailed description of a wild-type cuticle.] The effects of ubiquitous ANTP expression on the embryonic cuticle are well characterized and include an inhibition of head involution, the elimination of dorsal head structures, a transformation of $\mathrm{T} 1$ into a second thoracic segment (T2), and the appearance of one to two partial T2 denticle belts in the head segments /Gibson and Gehring 1988; Gibson et al. 1990). Our transgenic lines that express wild-type ANTP generate phenotypes that are essentially identical to this (Fig. 2B,G,J). Importantly, we and others observe no phenotypic consequences of ubiquitous wild-type ANTP expression in the cuticle posterior to and including $\mathrm{T} 2$ (Fig. 2B,J) (Gibson and Gehring 1988; Gibson et al. 1990). We refer to the phenotype induced by wild-type ANTP as a class II phenotype (Table 2).

Embryos that express ANTP ${ }^{[1,2,3,4] \mathrm{A}}$ ubiquitously show a pleiotropic phenotype that includes features of the class II phenotype as well as additional mutant phenotypes. We refer to the sum of these phenotypes as a class IV phenotype (Table 2 ). In class IV embryos, $\mathrm{T} 1$ is transformed into a T2 identity with complete loss of the T1 beard (Fig. 2D,E,H). The head segments of class IV embryos also appear to be transformed into a T2-like identity. All normal head structures are missing and two or three T2-like denticle belts are seen on the head (Fig. $2 \mathrm{H})$.

In addition to these class II characteristics, ANTP ${ }^{[1,2,3,4] A}$ generates additional phenotypes never observed after ubiquitous wild-type ANTP expression. These phenotypes include an absence of Keilin's organs, shortened denticle belts, and a failure to germ-band retract (Fig. 2D,E). Occasionally, individual denticles within the abdominal belts appear small and thoraciclike (Fig. $2 \mathrm{H}$ ). Approximately $25 \%-30 \%$ of these embryos exhibit defects at the posterior terminus including reduced anal pads, anal tuft, and filzkörper (Fig. 2K). The shortened denticle belts ranged from 30 to $70 \%$ of their normal width (Fig. 2D). The strong head and T1 transformations, lack of Keilin's organs, shortened denticle belts, and failure of germ-band retraction are seen in $>95 \%$ of the embryos containing two copies of the HS:Antp ${ }^{[1,2,3,4] A}$ gene (Table 2). Thus, a form of ANTP that is mutant at all four of its putative CKII target sites retains some normal ANTP functions but also has additional functions not seen with wild-type ANTP.

The class IV phenotype seen in HS:Antp $p^{[1,2,3,4] A} \mathrm{em}-$ bryos is dosage-sensitive. Embryos expressing one copy of HS:Antp ${ }^{[1,2,3,4] A}$ show a class II phenotype (Table 2; Fig. 2Cl, whereas embryos containing two copies of $H S: A n t p^{[1,2,3,4] A}$, even when the two copies are on different chromosomes, show the novel class IV phenotype. Importantly, the class IV phenotype is not generated by wild-type ANTP, even when $H S$ :Antp embryos are given multiple heat shocks or when multiple copies of the HS:Antp transgene are present (data not shown).

\section{ANTP ${ }^{[1,2,3,4] A}$ binds DNA to generate the class IV phenotype}

ANTP ${ }^{[1,2,3,4] A}$ could generate the class IV phenotype independently of its ability to bind DNA, perhaps by forming inappropriate protein-protein associations. Alternatively, the class IV phenotype may result because ANTP ${ }^{[1,2,3,4] A}$ has a different DNA-binding specificity or affinity than wild-type ANTP. To determine whether DNA binding by ANTP ${ }^{[1,2,3,4] A}$ was important we mutated position 50 of the homeodomain in the ANTP ${ }^{[1,2,3,4] \mathrm{A}}$ coding sequence to Ala. This residue, which is a glutamine in all HOX proteins, is critical for DNA binding by these homeodomains (Hanes and Brent 1989; Treisman et al. 1989). This mutant cDNA $\left(A n t p^{11,2,3,4] A, Q 50 A}\right)($ Fig. 1A), was joined to the hsp70 promoter and transgenic fly stocks were generated. Although ANTP ${ }^{[1,2,3,4] \mathrm{A}, \mathrm{Q} 50 \mathrm{~A}}$ is able to block head involution and weakly alter the T1 identity, this protein is unable to generate the class IV phenotype (Table 2). 
Figure 2. Cuticle phenotypes generated by ANTP ${ }^{1,2,3,4] \mathrm{A}}$. $(A-E)$ Dark-field micrographs. Ventral view of a cuticle secreted by a wild-type embryo (A) showing the three thoracic (T1-T3) and eight abdominal (A1-A8) segments. In wild type, head segments are involuted inside the embryo at the anterior end $\{t o p\rangle$. (B) Ventral view of a cuticle secreted by a HS:Antp embryo that expressed wild-type ANTP ubiquitously (a class II phenotype). $(C)$ Ventral view of a cuticle secreted by an embryo containing a single copy of $H S: A n t p^{\{1,2,3,4] A}$ that expressed ANTP $^{[1,2,3,4] \mathrm{A}}$ ubiquitously (a strong class II phenotype). $(D, E)$ Ventral and lateral, respectively, views of cuticles secreted by embryos containing two copies of HS:Antp ${ }^{[1,2,3,4] A}$ that expressed ANTP ${ }^{[1,2,3,4] \mathrm{A}}$ ubiquitously (class IV phenotypes). $(F-H)$ Phase contrast micrographs of the anterior and ventral surfaces of wild type $(F), H S: A n t p(G)$, and HS:Antp ${ }^{[1,2,3,4] A}(H) \mathrm{cu}$ ticles. Wild-type ANTP $(G)$ transforms T1 into T2-like segment, partially blocks head involution, and only weakly transforms head segments. In contrast, ANTP ${ }^{[1,2,3,4] \mathrm{A}}(H)$ transforms $\mathrm{T} 1$ and two to three head segments into T2-like segments. Occasional thoracic-like denticles are observed in the abdominal segments of these cuticles (arrow). (I-K) Phase contrast micrographs of the posterior and ventral surfaces of wild type $\langle I\rangle, H S: A n t p(J)$, and HS:Antp ${ }^{[1,2,3,4] A}(K)$ cuticles. Wild-type ANTP (J) does not affect the morphology of these segments, including abdominal segment 8 (A8), the anal pad $(\mathrm{AP})$, anal tuft $(T)$, filzkörper $(F)$, and spiracles $(S)$. ANTP ${ }^{[1,2,3,4] \mathrm{A}}(K)$ reduces the size of $A 8$ and alters the morphologies of the anal pads and spiracles. Filzkörper and anal tufts are often missing from these cuticles.
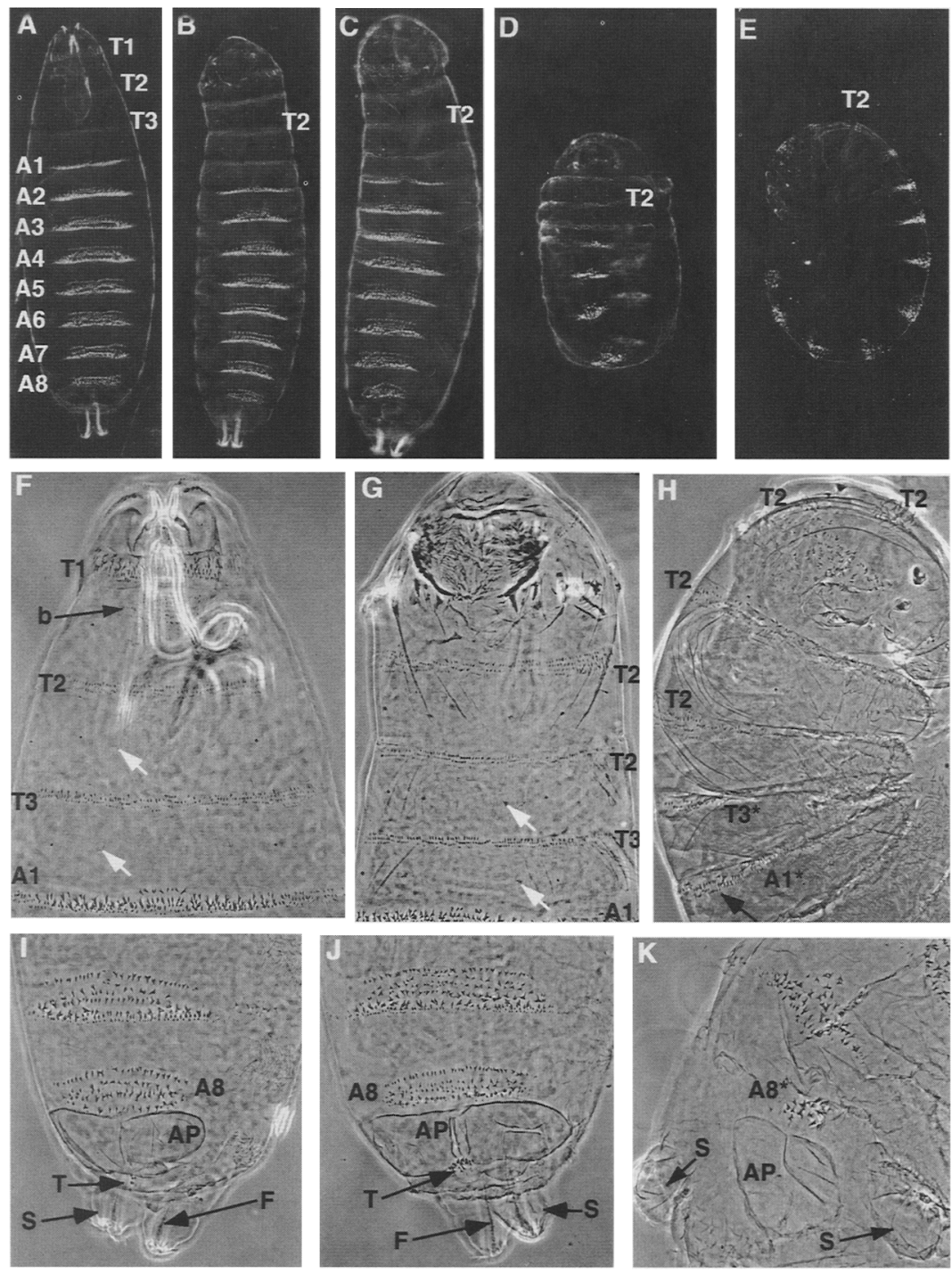

Therefore, amino acid Q50 is important for the novel functions of ANT $\mathrm{P}^{[1,2,3,4] \mathrm{A}}$. These results suggest that ANTP ${ }^{[1,2,3,4] A}$ must bind DNA to generate the class IV phenotype.

\section{ANTP(1,2,3,4]A alters the expression of several dorsal/ventral markers}

The class IV phenotype of embryos expressing ubiquitously two copies of $H S: A n t p^{[1,2,3,4] A}$ is reminiscent of the phenotype of embryos mutant for the Drosophila epidermal growth factor (EGF) receptor (DER). DER mutant embryos have shorter denticle belts, have a loss of ventral structures, and fail to germ-band retract (Price et al. 1989; Schejter and Shilo 1989; Raz and Shilo 1993). Given these similarities, we tested whether embryos that express ANTP ${ }^{[1,2,3,4] \mathrm{A}}$ ectopically showed abnormal expression patterns of genes involved in dorsal/ventral development during embryogenesis. We used an antiDER antibody to detect DER protein and in situ hybrid- ization to detect expression of the genes argos, an inhibitor of the DER pathway (Freeman et al. 1992), and spitz, a putative DER ligand (Rutledge et al. 1992). All three of these genes were expressed normally in these embryos (data not shown). Thus, the class IV phenotype cannot be explained by the altered expression of these genes.

However, this was not the case for the gene rhomboid (rho). The RHO protein contains seven transmembrane domains and is thought to promote transmission of the EGF signal to the cell (Sturtevant et al. 1993). At $\sim 4.5-7.5$ $\mathrm{hr}$ of development $r$ ho expression is detected normally in cells of the ventral midline and in one ventral-lateral cluster of cells per hemisegment, including the cells of the tracheal pits and the precursors of the chordotonal organs (Bier et al. 1990). In embryos expressing ANTP $^{[1,2,3,4] \mathrm{A}}$ rho expression in these ventral-lateral clusters was greatly reduced or absent (Figure $3 \mathrm{~B}$ ). In contrast, rho expression in the ventral midline was normal. tho expression in embryos expressing ectopic wild-type ANTP was completely normal (Fig. 3A). Another marker 
Table 2. Phenotypes generated by ANTP and ANTP mutants

\begin{tabular}{|c|c|c|c|c|c|c|c|}
\hline \multirow[b]{2}{*}{ Genotype of parents ${ }^{a}$} & \multirow[b]{2}{*}{$n^{\mathrm{b}}$} & \multicolumn{5}{|c|}{ Percentage of larvae in each class ${ }^{c}$} & \multirow[b]{2}{*}{ Comments $^{\mathrm{d}}$} \\
\hline & & WT & I & II & III & IV & \\
\hline$\frac{\text { HS:Antp }}{\text { Cyo }}$ & 212 & 20 & 0 & 75 & 5 & 0 & $75 \% 1$ or 2 copies \\
\hline$\frac{\text { HS:Antp }}{\text { HS:Antp }^{[1,2,3,4] \mathrm{A}}}$ & 422 & 0 & 0 & 0 & 5 & 95 & $100 \% 2$ copies \\
\hline 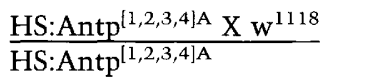 & 182 & 0 & 0 & $95^{\mathrm{e}}$ & 5 & 0 & $100 \% 1$ copy \\
\hline 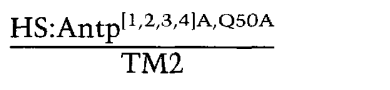 & 405 & 18 & 0 & $65^{\mathrm{f}}$ & 13 & 3 & $25 \% 2$ copies \\
\hline$\frac{\text { HS:Antp }}{\text { TM2 } 2}$ & 297 & 26 & $74^{\mathrm{g}}$ & 0 & 0 & 0 & $75 \% 1$ or 2 copies \\
\hline$\frac{\text { HS:Antp }}{\text { HS:Antp }}\left[\begin{array}{l}{[1,2] \mathrm{A}} \\
\text { He }\end{array}\right.$ & 570 & 0 & 0 & 93 & 4 & 2 & $100 \% 2$ copies \\
\hline$\frac{\mathrm{HS} \text { Antp }}{\text { Cyo }} \frac{\text { HS:Antp }}{\text { TM2 }}$ & 212 & 13 & 0 & 81 & 3 & 3 & $-31 \% \geqslant 3$ copies \\
\hline 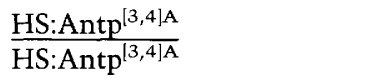 & 503 & 0 & 0 & 56 & 28 & 16 & $100 \% 2$ copies \\
\hline$\frac{\text { HS:Antp }}{\text { TM } 2}$ & 352 & 26 & 0 & 47 & 3 & 24 & $25 \% 2$ copies \\
\hline
\end{tabular}

${ }^{\mathrm{a}}(\mathrm{HS})$ hsp 70 promoter.

$\mathrm{b}(n)$ Total number of larvae scored.

(WT) wild type, TM2/TM2, or Cyo/Cyo. (Class I) Weak block in head involution and abnormal cephalopharyngeal skeleton, no T1 to T2 transformation. (Class II) Weak head to T2 transformation; strong T1 to T2 transformation. (Class III) Head and T1 strongly transformed to T2; either a curled head or a failure to germ-band retract. (Class IV) Head and T1 strongly transformed to T2; dorsal/ventral abnormalities; abnormalities at the posterior end.

${ }^{\mathrm{d}}$ Listed are the percentage of embryos containing the relevant number of copies of the heat shock transgene.

eAll of these larvae have a stronger than average class II phenotype.

${ }^{\mathrm{f}}$ Approximately $50 \%$ of these larvae have a weaker than average class II phenotype.

${ }^{8}$ Approximately $7 \%$ of these larvae are curled.

for tracheal pit cells, evenskipped (Frasch et al. 1987), was expressed normally in embryos that ectopically express $\operatorname{ANTP}^{[1,2,3,4] A}$ (data not shown). In addition, the tracheal pits are present in these embryos as viewed by Nomarski optics. These results suggest that ANTP ${ }^{[1,2,3,4] \mathrm{A}}$ specifically represses a subset of the rhomboid expression pattern while leaving general tracheal pit development unperturbed.

The decapentaplegic (dpp) gene encodes a member of the transforming growth factor beta family (Padgett et al. 1987). In germ-band-elongated embryos $d p p$ is expressed in distinct dorsal and ventral-lateral rows of cells as well as in other cell types (St. Johnston and Gelbart 1987). ANTP $^{[1,2,3,4] \mathrm{A}}$, but not wild-type ANTP, was able to induce ectopic dpp expression; in 7- to 10-hr Antp ${ }^{1,2,3,4] A}$ embryos additional $d p p$-expressing cells were observed between the dorsal and ventral rows (Fig. 3, D vs. C). In addition, the ventral-lateral row of $d p p$-expressing cells in $A n t p^{11,2,3,4] A}$ embryos appeared thicker and these cells appeared to express higher than wild-type levels of DPP.

A derivative of ventral embryonic cells is the central nervous system (CNS). To test for defects in the CNS, we stained 11- to 14-hr embryos with an anti-horseradish peroxidase (HRP) antibody, which labels cells of the CNS (Mayer and Nusslein 1988). Embryos that express ANTP ${ }^{[1,2,3,4] \mathrm{A}}$ showed a disorganized CNS with irregularly spaced or fused horizontal commissures and gaps in the longitudinal commissures (Fig. 3F). These defects were not observed in embryos that express wild-type ANTP ectopically (Fig. 3E).

\section{ANTP ${ }^{[1,2,3,4] A}$ regulates several homeotic target genes inappropriately}

We continued the molecular characterization of the class IV phenotype by analyzing the expression of several homeotic target genes and the homeotic genes themselves. The gene teashirt (tsh) is expressed in trunk segments and is inducible in the head by ectopic expression of ANTP or UBX (Roder et al. 1992; McCormick et al. 1995). Embryos expressing ANTP ${ }^{[1,2,3,4] \mathrm{A}}$ ubiquitously show an induction of $t s h$ expression in a manner that appeared indistinguishable from that induced by ubiquitous wild-type ANTP expression (Fig. 4B).

The Distal-less (DII) gene encodes a homeodomain protein required for the development of the Keilin's or- 

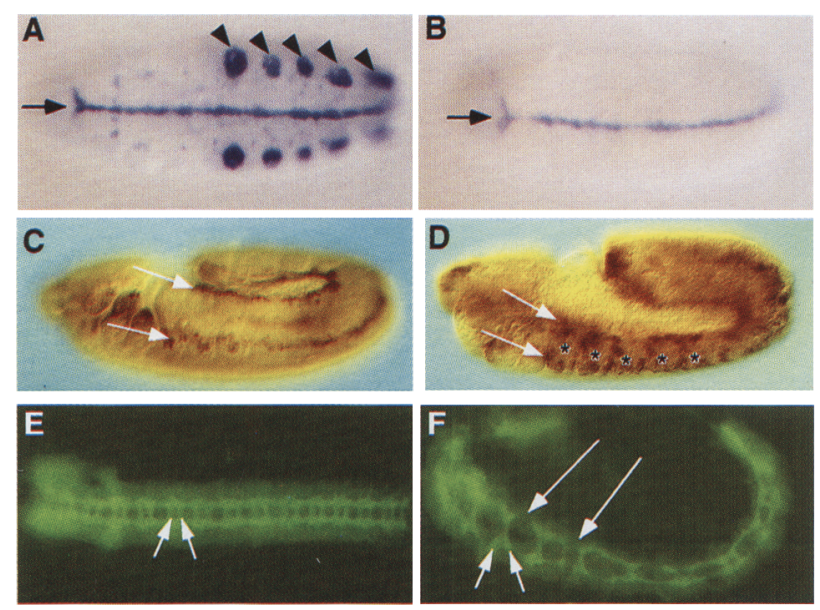

Figure 3. ANTP ${ }^{[1,2,3,4] \mathrm{A}}$ alters gene expression along the dorsal/ventral axis. The embryos in $A, C$, and $E$ expressed wildtype ANTP ubiquitously and the embryos in $B, D$, and $F$ expressed ANTP ${ }^{[1,2,3,4] A}$ ubiquitously. The expression patterns in $A, C$, and $E$ are identical to wild type. $(A, B)$ Ventral views of stage 10 embryos stained for tho mRNA by in situ hybridization. Ventral midline (arrow) expression is not affected, whereas the lateral patches (arrowheads) are repressed by ANTP ${ }^{[1,2,3,4] \mathrm{A}}$. $(C, D)$ Lateral views of stage 11 embryos stained for DPP protein using an anti-DPP antibody. In wild-type or HS:Antp embryos $(C)$, DPP is visible in two stripes along the anteroposterior axis (arrows). In HS:Antp ${ }^{[1,2,3,4] A}$ embryos (D) ectopic DPP staining is visible between the two stripes (asterisks). $(E, F)$ Stage $14 \mathrm{em}-$ bryos stained for CNS integrity using an anti-HRP antibody. ANTP $P^{[1,2,3,4] A}$ expression results frequently in gaps in the longitudinal commissures (long arrows) and fusions of the horizontal commissures (small arrows).

gans in the embryo and limbs of the adult (Sunkel and Whittle 1987; Cohen et al. 1989). D11 is expressed normally in two clusters of cells in each thoracic segment, as well as in head segments. Interestingly, Dll expression is reduced in the head segments and eliminated or nearly eliminated in the thoracic segments of 6- to 9-hr embryos that express ANTP ${ }^{[1,2,3,4] \mathrm{A}}$ ubiquitously (Fig. 4D). This is consistent with the loss of Keilin's organs in class IV larvae (Fig. 2H). In contrast, ectopic expression of wild-type ANTP did not affect Dll expression (Fig. 4C). DIl can also be repressed by the homeotic proteins UBX and Abdominal-A (ABD-A) (Vachon et al. 1992). Therefore, we checked whether ANTP ${ }^{[1,2,3,4] \mathrm{A}}$ might repress DIl by activating these abdominal homeotic genes inappropriately. This was not the case. Embryos expressing ANTP $^{[1,2,3,4] \mathrm{A}}$ showed wild-type patterns of $U b x, a b d-A$, and $A b d-B$ expression (data not shown). Thus, ANTP $^{[1,2,3,4] A}$ represses DIl independently of the abdominal homeotic genes.

Expression of $d p p$ in PS7 of the visceral mesoderm (VM) has been studied extensively (for review, see Bienz 1994). UBX and the homeodomain protein Extradenticle (EXD) are required for the expression of $d p p$ in this tissue (Chan et al. 1994; Rauskolb and Wieschaus 1994). In contrast, Antp is not thought to regulate $d p p$ in the VM.
Ectopic expression of wild-type ANTP has no effect on $d p p$ expression in the VM (Fig. 4E). However, antibody staining of 7- to 10-hr embryos revealed that $d p p$ expression in the VM was induced in embryos that expressed ANTP $P^{[1,2,3,4] A}$ ubiquitously. In approximately half of these embryos an anterior expansion of $d p p$ expression in the VM was observed (Fig. 4F). In contrast, ANTP $P^{[1,2,3,4] \mathrm{A}}$ does not induce UBX expression in this tissue (data not shown).

Expression of empty spiracles (ems) in PS8 is activated directly by ABD-B (Jones and McGinnis 1993). Embryos mutant for ems lack filzkörper and show an empty posterior spiracles phenotype (Dalton et al. 1989). ems expression was analyzed in 6- to 9-hr embryos containing an ems-lac $Z$ reporter gene that expresses $\beta$-galactosidase in a portion of PS8 in an $A b d$ - $B$-dependent manner (Jones and McGinnis 1993). In $~ 25 \%-30 \%$ of embryos expressing $\operatorname{ANTP}^{[1,2,3,4] \mathrm{A}}$, expression of the ems-lac $Z$ reporter
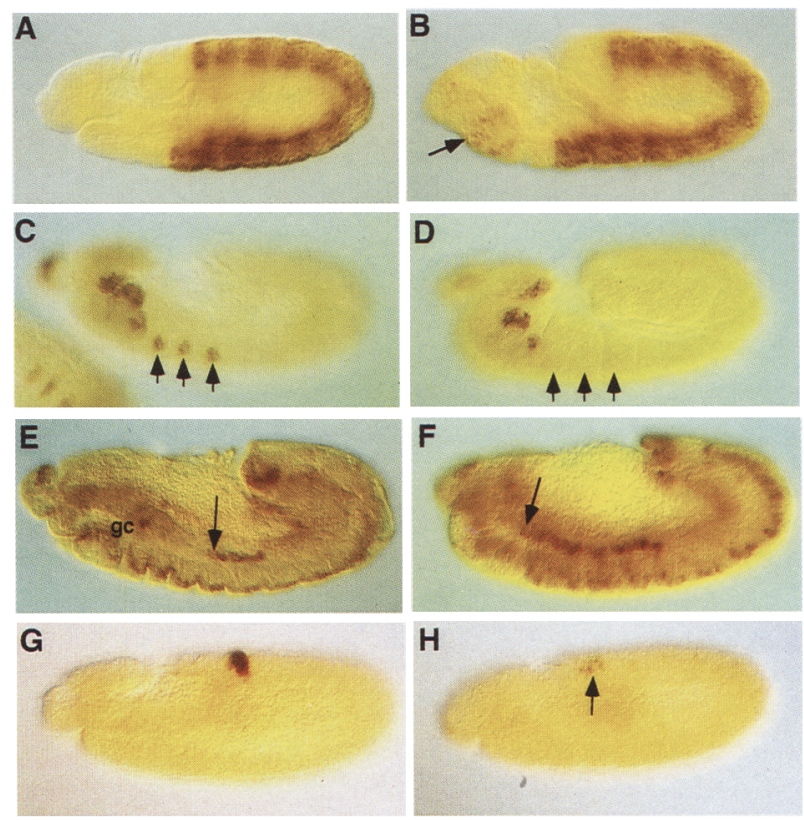

H

Figure 4. $A N T P^{[1,2,3,4] A}$ misregulates homeotic target genes. $(A, B)$ Stage 10 wild-type $(A)$ and $H S: A n t p^{[1,2,3,4] A}(B)$ embryos stained for TSH protein using an anti-TSH antibody. ANTP ${ }^{[1,2,3,4] \mathrm{A}}$ induces TSH expression in the head (arrow) as does wild-type ANTP (not shown). (C,D) Stage 11 HS:Antp $(C)$ and $H S: A n t p^{[1,2,3,4] A}(D)$ embryos stained for DLL protein. Unlike wild-type ANTP, ANTP ${ }^{[1,2,3,4] \mathrm{A}}$ eliminated DLL in all three thoracic segments (arrows) and partially repressed DLL in head segments. $(E, F)$ Stage $11 \mathrm{HS}: A n t p(E)$ and HS:Antp ${ }^{[1,2,3,4] A}|F|$ embryos stained for DPP protein. The gastric caeca $(\mathrm{gc})$ primordia is a normal position of DPP expression. Unlike ANTP, ANTP ${ }^{[1,2,3,4] \mathrm{A}}$ induced ectopic DPP expression in the anterior portion of the $\mathrm{VM}$; the arrows point to the anterior limits of DPP expression. $\{G, H\rangle$ Stage 10 HS:Antp $|G|$ and $H S: A n t p^{(1,2,3,4 j A}(H)$ embryos carrying an ems-lacZ reporter gene stained for $\beta$-galactosidase. Unlike wild-type ANTP, ANTP ${ }^{[1,2,3,4] A}$ represses ems-lacZ expression in PS8. Despite the ubiquitous and high levels of wild-type ANTP in C, E, and $G$, these expression patterns are the same as wild type. 
gene was greatly diminished (Fig. $4 \mathrm{H}$ ). In contrast, expression of the reporter gene was unaffected by expression of wild-type ANTP (Fig. 4G). This result is consistent with the cuticle phenotype of embryos expressing ANTP $^{[1,2,3,4] \mathrm{A}}$ in that a similar frequency of these embryos were missing or had reduced filzkörper. $A b d-B$ expression in embryos expressing $\operatorname{ANTP}^{[1,2,3,4] \mathrm{A}}$ is normal (data not shown). These results indicate that, unlike wild-type $\mathrm{ANTP}, \mathrm{ANTP}^{[1,2,3,4] \mathrm{A}}$ is not functionally suppressed by $A B D-B$; instead, the normal function of $\mathrm{ABD}-\mathrm{B}$ as an activator of ems in PS8 is compromised by the presence of $\mathrm{ANTP}^{[1,2,3,4] \mathrm{A}}$.

\section{ANTP ${ }^{[1,2,3,4] E}$ is hypoactive in vivo}

To further investigate the role of phosphorylation in ANTP function, we expressed ubiquitously a form of ANTP in which the four putative CKII target sites were changed to glutamate residues (ANTP ${ }^{[1,2,3,4] E}$ ) (see Fig. 1A). The negative charges introduced by these changes might mimic a form of ANTP that is phosphorylated constitutively at these sites (e.g., see Cowley et al. 1994; Papavassiliou et al. 1995). The Antp $p^{[1,2,3,4] E}$ cDNA was joined to the $h s p 70$ promoter in a standard CaSpeR Pelement vector and transgenic fly stocks were generated. Embryos expressing ANTP ${ }^{[1,2,3,4] E}$ ubiquitously show very weak phenotypes; the heads of these embryos have a slight block in head involution and a partial reduction in the cephalopharyngeal skeleton (referred to here as a class I phenotype; Table 2) (Fig. 5B,D). Importantly, ubiquitous expression of ANTP ${ }^{[1,2,3,4] E}$ is unable to generate a T1-T2 (class II) transformation nor does it affect the development of the abdomen (Table 2). However, when expressed in vivo $\operatorname{ANTP}^{[1,2,3,4] \mathrm{E}}$ is present in nuclei at similar levels as ANTP or ANTP ${ }^{[1,2,3,4] \mathrm{A}}$ (data not shown) and, in vitro, $\operatorname{ANTP}^{[1,2,3,4] E}$ binds to an ANTP. binding site as well as wild-type ANTP (see below). These results suggest that a constitutively phosphorylated form of ANTP has reduced activity in vivo and cannot generate a T2 identity.

\section{CKII sites 1 and 4 are the most important}

To determine which of the mutations in ANTP ${ }^{[1,2,3,4] A}$ are important for the class IV phenotype we mutated subsets of the CKII consensus sites and characterized the effects of these proteins in vivo (see Fig. 1A). Embryos expressing ANTP ${ }^{[1,2] A}$ show a standard class II phenotype, even when expressed in multiple copies (Table 2; Fig. 6B). Just over half of the embryos expressing ANTP ${ }^{[3,4] A}$ ubiquitously also show a class II transformation. However, close to half of these embryos have additional abnormalities (Table 2). Approximately $16 \%$ of these embryos exhibit a class IV phenotype and $28 \%$ of these embryos exhibit an intermediate class III phenotype (Fig. 6C). Class III embryos have very strong transformations of $\mathrm{T} 1$ and head segments to $\mathrm{T} 2$ and in addition have either a curled head or curled tail, indicating a partial failure in germ-band retraction.

Interestingly, $\mathrm{ANTP}^{[1,4] \mathrm{A}}$ behaves similarly to $\mathrm{ANTP}^{[1,2,3,4] \mathrm{A}}$. Embryos expressing ubiquitously two copies of $\mathrm{ANTP}^{[1,4] \mathrm{A}}$ show a strong class IV phenotype (Fig. 6D), whereas embryos expressing one copy of ANTP ${ }^{[1,4] A}$ generate a class II phenotype (Table 2). In

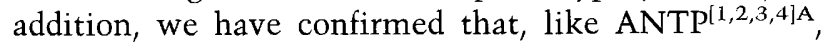
ANTP $^{[1,4] \mathrm{A}}$ represses specifically the ventral lateral expression of rho (data not shown; Fig. 3B). However, there is more variability from line to line than is seen with ANTP $[1,2,3,4] \mathrm{A}$, suggesting that $\operatorname{ANTP}^{[1,4] \mathrm{A}}$ may be slightly less active. Nevertheless, these data suggest that of the four CKII sites, mutations in sites 1 and 4, which by sequence are the best CKII sites, are the most important for generating the class IV phenotype. However, mutations at sites 2 and 3 may also contribute to the novel functions exhibited by $\operatorname{ANTP}^{[1,2,3,4] \mathrm{A}}$.

\section{ANTP 1.D,4.EJA generates the class IV phenotype}

The experiments described above indicate that phosphorylation at sites 1 and 4 are important for controlling ANTP activity in vivo. Although these sites best match the CKII consensus target sequence it is possible that another kinase phosphorylates these sequences in vivo. As there are no available deficiencies of or point mutations in the gene encoding the catalytic subunit of CKII, we relied on a highly conserved feature of the CKII target sequence to further implicate this kinase in modulating ANTP function. Specifically, we mutated the acidic residues at the +3 position at sites 1 and 4 to alanines to
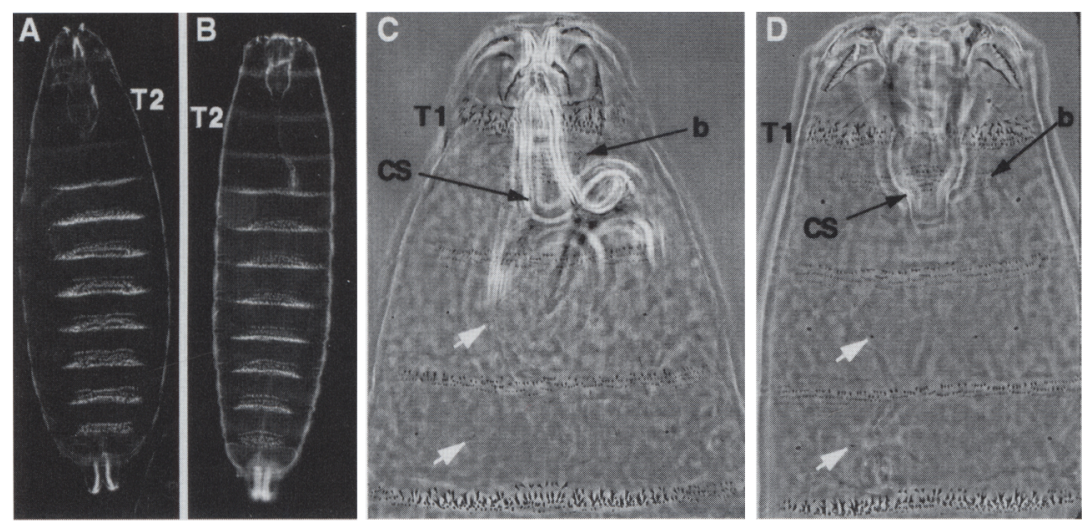

Figure 5. $\operatorname{ANTP}^{[1,2,3,4] \mathrm{E}}$ is hypoactive in vivo. $\langle A, B\}$ Dark-field micrographs showing the ventral surfaces of cuticles secreted by wild-type $(A)$ and $H S: A n t p^{(1,2,3,4 / E}(B)$ embryos. T2 indicates the position of the second thoracic denticle belt. $(C, D)$ Phase contrast micrographs of the anterior and ventral surfaces of the cuticles in $A$ and $B$, respectively. ANTP ${ }^{[1,2,3,4] \mathrm{E}}$ does not transform $\mathrm{T} 1$ as indicated by the normal T1 denticle belt and $\mathrm{T} 1$ beard (b). $\operatorname{ANTP}^{[1,2,3,4] E}$ subtly affects head development by reducing the size of the cephalopharyngeal skeleton (CS). The cuticles in $B$ and $D$ illustrate a class I phenotype. 

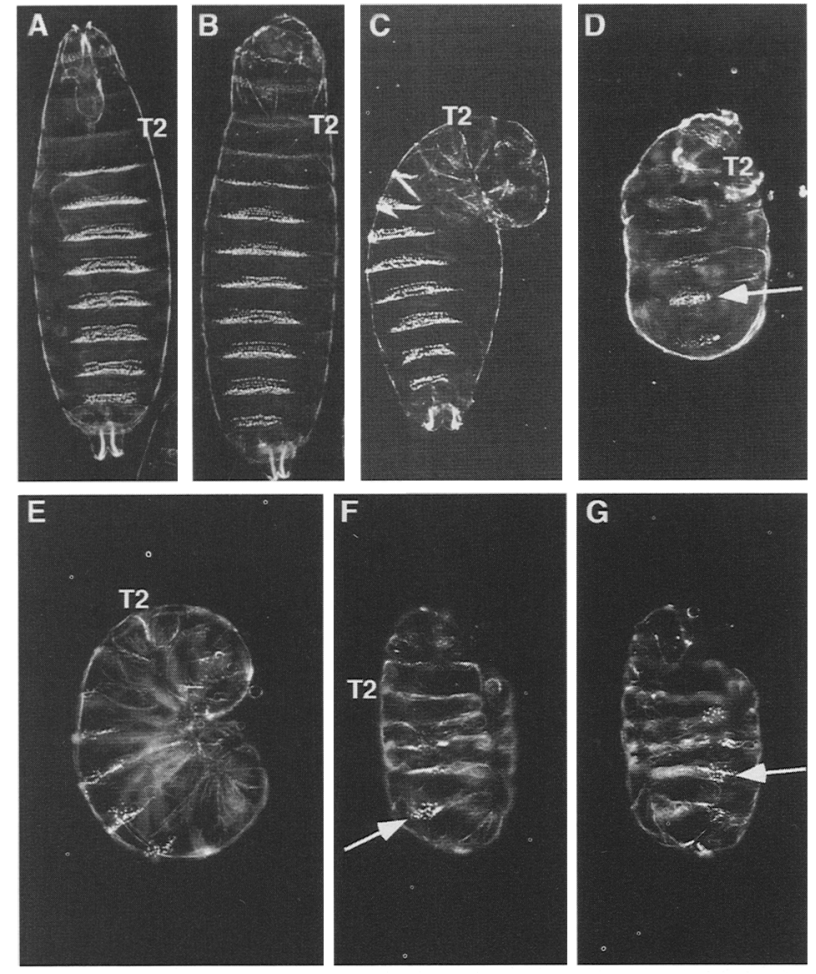

Figure 6. Mutating CKII sites 1 and 4 is sufficient to generate the class IV phenotype. $(A-G)$ Dark-field micrographs of cuticles secreted by wild-type $(A), H S: A n t p^{[1,2\} A}(B), H S: A n t p^{\{3,4\} A}(C)$, $H S: A n t p^{(1,4] A}(D)$, and HS:Antp ${ }^{[1 . D, 4 . E] A}(E-G)$ embryos. T2 indicates the position of the second thoracic denticle belt. Expression of ANTP ${ }^{[1,2] A}, \operatorname{ANTP}^{[3,4] A}$, ANTP $^{[1,4] A}$, and ANTP ${ }^{[1 . D, 4 . E] A}$ proteins generate class II, III, IV, and IV phenotypes, respectively. $(A-D)$ Vental views, $(E)$ lateral view; $(F, G)$ different focal planes of the same embryo showing the anterior $(F)$ or posterior $(G)$ halves. The arrows in $D, F$, and $G$ point to examples of highly shortened abdominal denticle belts that are typical of the class IV phenotype.

generate ANTP ${ }^{1 . D, 4 . E] A}$ (see Fig. 1A). Because CKII requires an acidic amino acid at this position (Marchiori et al. 1988) the strong prediction is that if CKII is the relevant kinase in vivo ANTP ${ }^{[1 . D, 4 . E] A}$ should also generate the class IV phenotype. In fact, when expressed ubiquitously through the $h s p 70$ promoter ANTP ${ }^{[1 . D, 4 . E] A}$ is able to generate the class IV phenotype (Fig. 6E-G). This result provides strong evidence that phosphorylation at sites 1 and 4 by CKII, or by a kinase with a very similar substrate specificity, is important for modulating ANTP activity in vivo.

\section{CKII phosphorylates ANTP, but not ANTP(1,2,3,4]A, in vitro}

To determine whether ANTP is normally a substrate for CKII, an in vitro kinase assay was performed using purified Drosophila CKII and recombinant ANTP proteins. Normal and mutated forms of ANTP were expressed as glutathionine $S$-transferase (GST) fusion proteins in
Escherichia coli. Each protein was used as a substrate in an in vitro kinase assay (Saxena et al. 1987). Wild-type ANTP protein, as well as ANTP ${ }^{[1,2] \mathrm{A}}$, can be phosphorylated by CKII in vitro (Fig. 7, lanes 3,4). The amount of phosphorylation of ANTP ${ }^{[1,2] \mathrm{A}}$ appeared slightly reduced compared to the phosphorylation of wild-type ANTP. In contrast, ANTP $P^{[3,4] A}$ and ANTP ${ }^{[1,2,3,4] A}$ were not phosphorylated (Fig. 7, lanes 5,6). Therefore, under these reaction conditions, sites 3 and/or 4 are substrates for CKII phosphorylation in vitro.

ANTP(1,2,3,4]E, but not $A N T P^{[1,2,3,4] A}$, is impaired in its ability to form complexes with EXD

As the novel activities of ANTP ${ }^{[1,2,3,4] \mathrm{A}}$ probably depend on DNA binding (see above), we characterized the ability of ANTP, ANTP ${ }^{[1,2,3,4] \mathrm{A}}$, and ANTP ${ }^{[1,2,3,4] \mathrm{E}}$ to bind DNA using the electrophoretic mobility-shift assay (EMSA). We were unable to test ANTP protein that had been phosphorylated in vitro by CKII because site 1 , and to some extent site 4 , is not phosphorylated quantitatively under our reaction conditions (Fig. 7; data not shown). Initially we compared binding to oligonucleotides containing a strong ANTP-binding site, 5'-TAATGG. ANTP, ANTP ${ }^{[1,2,3,4] \mathrm{A}}$, and ANTP ${ }^{[1,2,3,4] \mathrm{E}}$ have similar affinities for this binding site (Fig. 8A). Thus, neither the Glu nor the Ala substitutions affected the ability of ANTP to recognize and bind to this sequence.

HOX proteins can bind to DNA cooperatively with the homeodomain protein EXD or its mammalian homologs, the PBX proteins and, in vivo, exd is important for HOX function (for review, see Mann and Chan 1996). There-

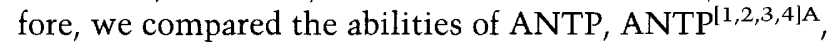
and $\operatorname{ANTP}^{(1,2,3,4] E}$ to bind to DNA cooperatively with

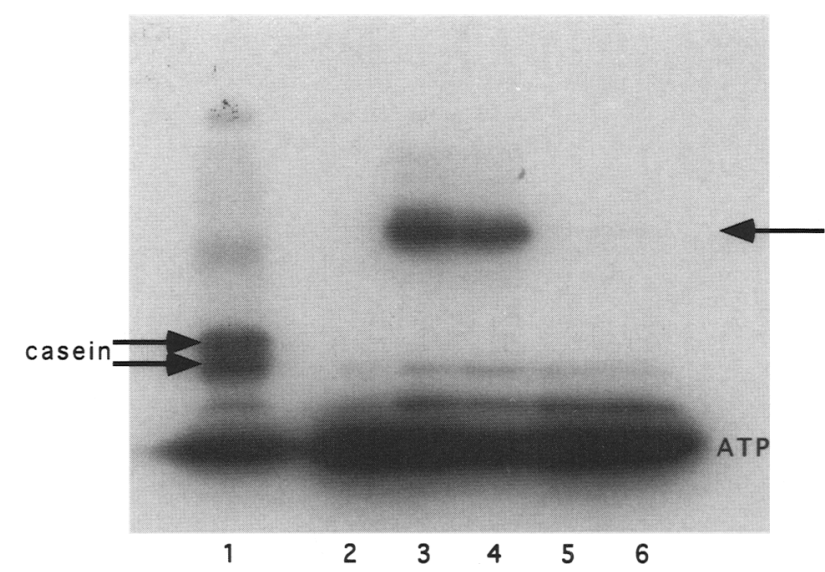

Figure 7. ANTP, but not $\mathrm{ANTP}^{[1,2,3,4] \mathrm{A}}$, is a substrate for CKII in vitro. Casein (lane 1), GST (lane 2), GST-ANTP (lane 3), GST-ANTP ${ }^{[1,2] \mathrm{A}}$ (lane 4), GST-ANTP ${ }^{[1,2,3,4] \mathrm{A}}$ (lane 5), or GSTANTP $^{[3,4] \mathrm{A}}$ (lane 6) were phosphorylated in vitro by purified Drosophila CKII in the presence of $\left[{ }^{32} \mathrm{P}\right] \gamma \mathrm{ATP}$. SDS-PAGE and autoradiography was used to detect the labeled proteins. The arrow points to the phosphorylated GST fusion proteins. The fastest migrating band is unincorporated $\left[{ }^{32} \mathrm{P}\right] \gamma \mathrm{ATP}$. 
A

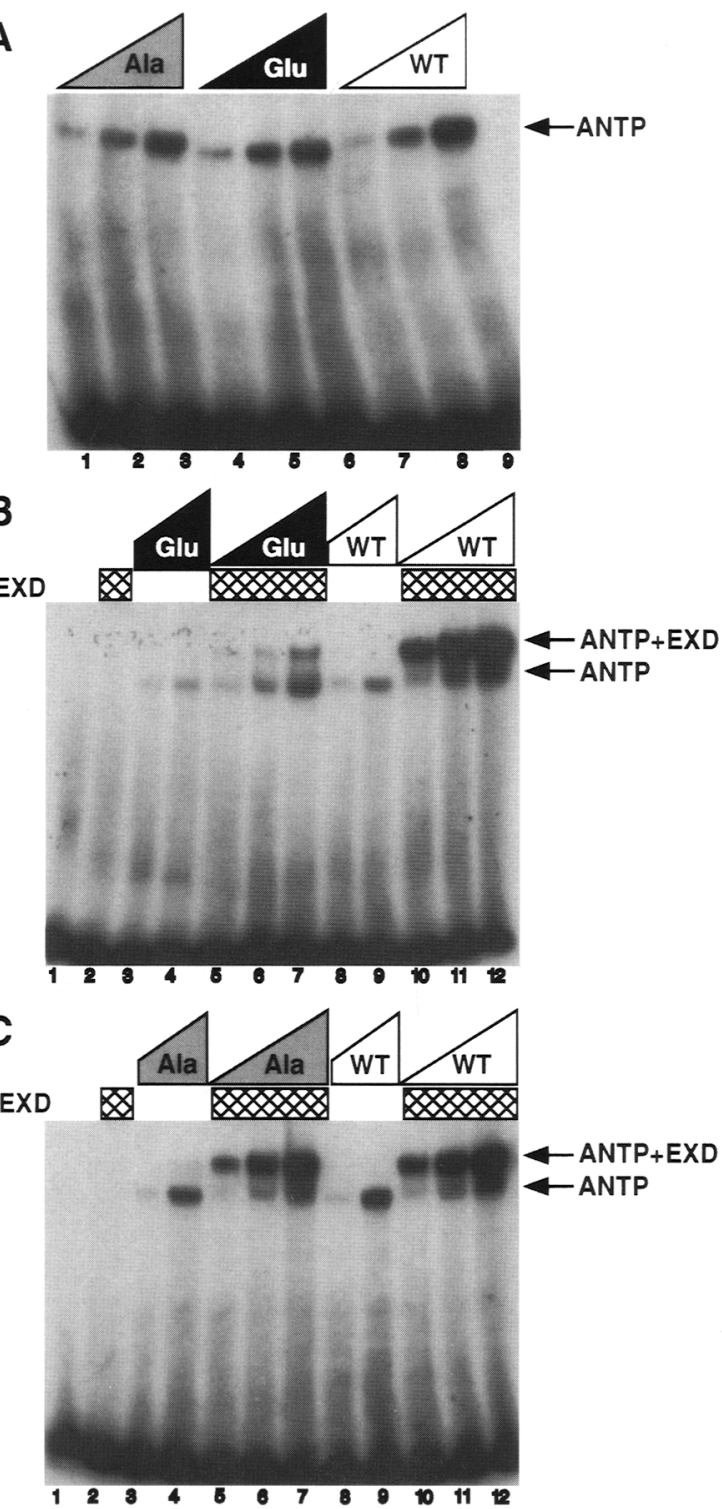

Figure 8. $A N T P^{[1,2,3,4] E}$ has a reduced ability to form complexes with EXD. (A) Band-shift (EMSA) experiments comparing binding of $\operatorname{ANTP}^{[1,2,3,4] \mathrm{A}}$ (Ala, lanes 1-3), $\operatorname{ANTP}^{[1,2,3,4] \mathrm{E}}$ (Glu, lanes 4-6), and ANTP (WT, lanes 7-9) binding to an oligonucleotide containing the consensus binding site $5^{\prime}$-TAATGG. $|B|$ Comparison of ANTP ${ }^{[1,2,3,4] \mathrm{E}}$ and ANTP binding to the HOXEXD binding site $5^{\prime}$-TGATTTATGG in the absence or presence of EXD as indicated. $(C)$ Comparison of ANTP $\mathrm{P}^{[1,2,3,4] \mathrm{A}}$ and ANTP binding to the HOX-EXD binding site $5^{\prime}$-TGATTTATGG in the absence or presence of EXD as indicated. The amounts of protein used were normalized to the estimated amounts of the full-length species present in the preparation.

EXD. We used the bipartite HOX-EXD binding site, $5^{\prime}$ TGATTTATGG, which is a poor ANTP monomer binding site but a good binding site for ANTP-EXD heterodimers (Fig. 8B, lanes 8-12). Strikingly, although ANTP and ANTP ${ }^{[1,2,3,4] \mathrm{A}}$ are both able to bind cooperatively with EXD to this binding site (Fig. 8C),
ANTP $\mathrm{P}^{[1,2,3,4] \mathrm{E}}$ is greatly reduced in its ability to form complexes with EXD (Fig. 8B). We quantitated this effect by measuring the ratio of the faster migrating complex (monomer) to the slower migrating complex (heterodimer) within single lanes. For wild-type ANTP the heterodimer/monomer ratio ranged from 4.8 to 7.1 (Fig. $8 \mathrm{~B}, \mathrm{C}$, lanes $10-12)$ and for ANTP ${ }^{[1,2,3,4] \mathrm{A}}$ this ratio ranged from 5.2 to 6.6 (Fig. 8C, lanes 5-7). Strikingly, for $\mathrm{ANTP}^{[1,2,3,4] \mathrm{E}}$ this ratio ranged from 0.6 to 0.9 (Fig. 8B, lanes 5-7). Thus, although its ability to bind DNA as a monomer is largely unaffected, the Glu-substituted protein is 5- to 10-fold less able to form complexes with EXD.

\section{Discussion}

Phosphorylation modulates ANTP function in vivo

We have used a yeast two-hybrid screen to identify the Ser/Thr kinase CKII as an ANTP-interacting protein. We show that a form of ANTP in which all four putative CKII sites have been abolished generates dramatic phenotypes outside ANTP's normal domain of action. Importantly, in addition to having novel functions ANTP ${ }^{[1,2,3,4] A}$ still retains many of ANTP's wild-type functions, as indicated by the T2 denticle belts that it generates in the T1 and head segments. Thus, the four mutations introduced into ANTP ${ }^{[1,2,3,4] \mathrm{A}}$ have not abolished the wild-type properties of this protein. Instead, the class IV phenotype suggests that by mutating these residues we have revealed additional functions that are normally repressed in wild-type ANTP. Moreover, it is unlikely that the global properties of this protein have been altered because ANTP ${ }^{[1,2,3,4] \mathrm{A}}$ has similar DNAbinding properties to ANTP and because the class IV phenotype is also generated by proteins with only two point mutations (ANTP ${ }^{[1 . D, 4 . E] A}$ and ANTP ${ }^{[1,4] A}$ ).

These results show a correlation between ANTP activity in vivo and ANTP's putative phosphorylation state. Specifically, ANTP ${ }^{[1,2,3,4] \mathrm{A}}$, which is no longer an in vitro substrate for CKII, is neomorphic in vivo, whereas $\operatorname{ANTP}^{[1,2,3,4] E}$, which mimics the phosphorylated state, is hypomorphic in vivo. This correlation suggests that in the wild-type embryo ANTP activity is controlled, at least in part, by phosphorylation. For example, the data suggest that ANTP must be unphosphorylated at these CKII sites to generate certain aspects of the T2 identity (e.g., the T2 denticle belt), but must be phosphorylated to prevent other, inappropriate activities (e.g., repression of $D l l$ and $r h o$ ). Furthermore, when expressed posterior to T2 through the heat shock promoter, ANTP may be phosphorylated to prevent other inappropriate activities (e.g., repression of ems and alteration of the dorsal/ventral axis). In summary, these results strongly suggest that phosphorylation of ANTP plays an important role in controlling ANTP activity in vivo.

Apart from these data, little is known about the role of phosphorylation in modulating the activity of the homeotic proteins. UBX has been shown to be a phos- 
phoprotein in vivo (Gavis and Hogness 1991) and monoclonal anti-UBX antibodies have been generated that are sensitive to the different phosphorylation states of UBX (Lopez and Hogness 1991). Interestingly, when used to stain embryos, antibodies that preferably recognize unphosphorylated forms of UBX labeled the CNS more strongly than the epidermis or mesoderm (Lopez and Hogness 1991). These data suggest that the different phosphorylation states of UBX may be distributed in a tissue-specific manner and may execute different functions in vivo. Although phosphorylation-sensitive antibodies have not been generated for ANTP, ANTP has been shown to be a phosphoprotein in vivo (S. Hayashi, pers. comm.).

\section{CKII may phosphorylate ANTP in vivo}

Several lines of reasoning suggest that CKII might be the kinase that is responsible for modulating ANTP function in vivo. First, ANTP and the $\alpha$ subunit of CKII interact directly and specifically in the yeast two-hybrid assay. This interaction is abolished when the putative CKII phosphorylation sites are changed to Ala. Second, wildtype ANTP, but not ANTP ${ }^{[1,2,3,4] \mathrm{A}}$, is phosphorylated in vitro by Drosophila CKII. Third, of the four mutated sites in $\operatorname{ANTP}^{[1,2,3,4] \mathrm{A}}, 1$ and 4, which are the most important for limiting the activity of ANTP in vivo, have the best match to an optimal CKII site and do not match the consensus site for any other known kinase. Fourth, mutation of the acidic amino acid at the +3 position of sites 1 and 4, which is an important component of a CKII target site, mimics mutation of the Ser or Thr at these sites. Finally, we note that site 4 appears to be conserved evolutionarily in Antp homologs. Sequence comparisons of Drosophila Antp, the three closest mouse Antp homologs a6, b6, and c6, as well as the Xenopus, zebra fish, chicken, and Caenorhabditis elegans (mab-5) Antp homologs, reveal that despite very little overall sequence similarity, all contain an optimal CKII target site carboxy-terminal to their homeodomains /Colberg-Poley et al. 1985; Schneuwly et al. 1986; Stroeher et al. 1986; Wright et al. 1987; Schughart et al. 1988, 1989; Wedden et al. 1989; Njlstad et al. 1990; Kenyon and Wang 1991). Moreover, six of eight of these proteins, including ANTP, show a conserved spacing of 7 or 8 amino acids between the homeodomain and the CKII target site. Although these findings strongly imply that CKII phosphorylates ANTP in vivo, a definitive test of this proposal must await the availability of mutations in the genes encoding the CKII subunits.

Phosphorylation by CKII has been reported to modulate the DNA-binding properties of several transcription factors (Manak et al. 1990; Berberich and Cole 1992; Hupp et al. 1992; Lin et al. 1992; Bourbon et al. 1995). For example, phosphorylation by CKII can have profound effects on the DNA-binding properties of the basic helixloop-helix proteins MYC and MAX. Whereas MAX homodimers and MYC/MAX heterodimers are able to bind to the same binding site when these proteins are unphos- phorylated, DNA binding by MAX homodimers, but not MYC/MAX heterodimers, is sharply reduced by CKII phosphorylation (Berberich and Cole 1992). CKII has also been shown to phosphorylate the Drosophila homeodomain protein Engrailed (EN) during embryogenesis (Bourbon et al. 1995). In this case the phosphorylated form of EN binds DNA better than the unphosphorylated form (Bourbon et al. 1995).

We suggest that phosphorylation of ANTP by CKII alters its DNA recognition properties. Although other mechanisms are possible, our data suggest that phosphorylation may affect the ability of ANTP to interact with cofactors such as the homeodomain protein EXD. The close proximity of site 4 carboxy-terminal to the ANTP homeodomain suggests that phosphorylation at this site might influence this protein-protein interaction and subsequent DNA binding. Consistent with them having a regulatory function, sequences carboxy-terminal to the homeodomains in the HOX proteins UBX and ANTP have been shown to influence the in vivo specificities of these proteins (Gibson et al. 1990; Chan and Mann 1993). We note, however, that a form of ANTP in which these sequences have been deleted still retains some of its in vivo functions (Gibson et al. 1990; Chan and Mann 1993). In contrast to these previous studies, the in vivo experiments presented here have all been carried out in the context of the full-length protein. Furthermore, the data presented here suggest that sequences in the amino-terminal portion of ANTP also contribute to this regulation because mutating only the carboxyterminal sites (in ANTP ${ }^{[3,4] \mathrm{A}}$ ) only partially affected activity in vivo. Thus, we conclude that in the context of the full-length protein phosphorylation at both aminoand carboxy-terminal sites modifies ANTP function, whereas truncated forms of ANTP that are missing some of these phosphorylation sites may not be regulated in this manner.

Candidate DNA elements that might respond differently to ANTP and ANTP ${ }^{[1,2,3,4] \mathrm{A}}$ include enhancers identified in the DIl, rho, and ems genes (Ip et al. 1992; Vachon et al. 1992; Jones and McGinnis 1993). Interestingly, sequences very similar to the ANTP-EXD binding site used here, 5'-TGATTTATGG, are present in the ems and rho enhancers, raising the possibility that the repression of these enhancers by $A N T P^{[1,2,3,4] \mathrm{A}}$ may be direct. In future experiments it will be interesting to address this question by characterizing the role of these binding sites in vivo.

Although our data suggest that phosphorylation at sites 1 and 4 alters ANTP's properties, they do not address the mechanism of regulation. In principle, although CKII is distributed uniformally during Drosophila embryogenesis (M. Abu-Shaar and R.S. Mann, unpubl.|, the activity of this kinase could be regulated. Alternatively, the regulation of phosphorylation at these sites could occur indirectly, perhaps as a secondary consequence of another post-translational modification ( $\mathrm{Pa}$ pavassiliou et al. 1995). These possibilities can be more easily distinguished once mutations in the genes encoding the two CKII subunits are available. 


\section{ANTP $P^{1,2,3,4] A}$ may not obey phenotypic suppression}

Two aspects of the class IV phenotype suggest that the activity of ANTP ${ }^{[1,2,3,4] \mathrm{A}}$ is not being suppressed by the more posterior homeotic proteins UBX, ABD-A, and ABD-B. First, in addition to being shorter, the abdominal denticle belts in class IV embryos occasionally have thoracic-like denticles. Such a mixture of thoracic and abdominal denticles is never observed after ubiquitous wild-type ANTP expression. Second, ANTP ${ }^{[1,2,3,4] \mathrm{A}}$ is able to repress ems inappropriately in PS8, which is activated normally by ABD-B. Repression by ANTP ${ }^{[1,2,3,4] A}$ occurs without altering $A b d-B$ expression, therefore, both ABD-B and ANTP $P^{[1,2,3,4] A}$ are present in these cells. However, unlike wild-type ANTP, ANTP ${ }^{[1,2,3,4] \mathrm{A}}$ is not suppressed phenotypically by ABD-B. Thus, based on these observations, we suggest that one mechanism underlying phenotypic suppression may be phosphorylation by kinases and, more specifically for ANTP, phosphorylation by CKII.

\section{Materials and methods}

\section{Two-hybrid screen}

The Gal4 DNA-binding fusion vector pAS1 and Y153 yeast strain were from S. Elledge (Durfee et al. 1993). pAS1-ANTP consists of the 445-bp RsaI fragment from pUAA (Chan and Mann 1993) encoding the homeodomain and carboxyl terminus of Antp cloned in-frame into a blunted BamHI site of pAS1. pAS1-UBX consists of the 430-bp RsaI fragment encoding the homeodomain and carboxyl terminus of $U b x$ cloned in-frame into a blunted BamHI site of pAS1 (Chan et al. 1994). pAS1ANTP $^{[3,4] \mathrm{A}}$ was constructed using PCR with ANTP $^{[3,4] \mathrm{A}}$, described below, as the template. This fragment was subcloned in-frame into pAS1 digested with NheI-BamHI. Expression in yeast of all Gal4 DNA-binding fusion proteins was confirmed by Western blot analysis using an anti-hemagglutinin (HA) antibody.

The Gal4 activation domain plasmid was pGADNOT (Luban et al. 1993). The Gal4 activation domain-directional cDNA library was constructed using cDNA synthesized from poly $(\mathrm{A})^{+}$ mRNA isolated from 3- to 12 -hr $w^{1118}$ Drosophila embryos using standard procedures (details provided upon request). The representation of the library was $-2 \times 10^{5}$ independent inserts with an average insert size of $\sim 2 \mathrm{~kb}$.

pAS1-ANTP was transformed into Y153 to make the strain Y.ANTP using the lithium-acetate method (Schiestle and Geitz 1989). Plasmid DNA from the pGADNOT-cDNA library was used to transform Y.ANTP. Colonies were tested for $\beta$-galactosidase activity using a standard filter assay. Plasmid DNA was isolated from blue colonies (Strathern and Higgins 1991) and used to transform E. coli DH5 $\alpha$ to ampicillin resistance. pGADNOT-cDNA plasmids were retested in Y.ANTP for interaction with ANTP and sequenced. Although present in the library, exd-encoding plasmids were not expected to be isolated in this screen because the "YPWM" motif was not present in the pAS1-ANTP construct.

\section{CaSpeR plasmids and mutagenesis}

The P-elements were derivatives of CaSpeR-Ia /Chan and Mann 1993). The BamHI-HpaI fragment containing most of the $U b x$ cDNA was replaced with various Antp cDNAs.
Mutagenic PCR reactions were performed using the Antp cDNA as a template. The $5^{\prime}$-untranslated region of Antp was removed such that all inserts began at a $B c / I$ site introduced just $5^{\prime}$ to the ATG codon. ANTP ${ }^{[1,2,3,4] \mathrm{A}}$ contained point mutations in the following codons: 35 , Thr $(\mathrm{ACC})$ to Ala $(\mathrm{GCC}) ; 84$, Ser (TCC) to Ala (GCC); 358, Thr (ACG) to Ala (GCA); 364, Ser (TCC) to Ala (GCC). ANTP ${ }^{[1,2] A}$, ANTP ${ }^{[3,4] A}$, and ANTP $P^{[1,4] A}$ contained the indicated subset of mutations. ANTP ${ }^{[1,2,3,4] \text { A, Q50A }}$ contained a Glu to Ala mutation at codon 346. Mutant codons in ANTP ${ }^{11,2,3,4] \mathrm{E}}$ were: 35 , Thr to Glu (GAA); 84 , Ser to Glu acid (GAA); 358, Thr to Glu (GAG); and 364, Ser to Glu (GAA). ANTP $^{[1 . D, 4 . E] A}$ contained mutations at codons 38 (Asp to Ala) and 367 (Glu to Ala). All Antp fragments were cloned as BcIIHincII fragments into CaSpeR Ia digested with BamHI-HpaI.

\section{Fly stocks and cuticle preparation}

All fly stocks had the $w^{1118}$ mutation to monitor the presence of the mini-white gene in the P elements. P-element transformation was carried out using standard procedures. At least two independent P-element insertions were studied for each construct. The ems enhancer line HZems1.2 is expressed in PS8 (Jones and McGinnis 1993). For cuticle analysis, embryos were collected for $3 \mathrm{hr}$, aged for $3 \mathrm{hr}$, and then heat shocked for 45 min at $37^{\circ} \mathrm{C}$. These embryos recovered $\sim 20 \mathrm{hr}$ at $25^{\circ} \mathrm{C}$ before cuticle preparation (Wieschaus and Nüsslein-Volhard 1986).

\section{Antibody staining}

For all experiments with the exception of the embryonic staining for $t$ sh expression, embryos were collected for $3 \mathrm{hr}$, aged for $3 \mathrm{hr}$, and heat shocked at $37^{\circ} \mathrm{C}$ for $45 \mathrm{~min}$. Embryos were recovered at $25^{\circ} \mathrm{C}$ for different lengths of time before fixation depending on the stage of embryogenesis to be analyzed. For tsh expression, embryos were collected for $6 \mathrm{hr}$ and then heat shocked three times at $37^{\circ} \mathrm{C}$ for $30 \mathrm{~min}$, with $30-\mathrm{min}$ recoveries at $18^{\circ} \mathrm{C}$ in between heat shocks as described (Gibson et al. 1990)

The following antibodies were used: anti-DLL (Vachon et al. 1992), anti-TSH (Zeng et al. 1993), anti-DPP (Panganiban et al. 1990), anti-HRP (Mayer and Nüsslein 1988), anti-ANTP (Glicksman and Brower 1988), anti-Ubx (White and Wilcox 1985), anti-ABD-A (Karch et al. 1990); anti-ABD-B (Celniker et al. 1989), and anti-DER (Zak and Shilo 1992).

\section{In situ hybridization}

Embryos were fixed and hybridized with RNA probes as described (Jiang et al. 1991). The rho (Bier et al. 1990) and spitz (Rutledge et al. 1992) RNA probes were provided by J. Jiang and S. Greenwood (Columbia University, New York, NY). The argos RNA probe (Freeman et al. 1992) was synthesized with T7 RNA polymerase using a subclone of the gene in pBluescript.

\section{In vitro kinase assay}

The Bcll-HincIl fragments of the Antp cDNAs were cloned into pGEX2t digested with BamHI-SmaI to create GST-ANTP fusion constructs. GST-ANTP encoding plasmids were grown in the E. coli DH5 $\alpha$. Protein expression was induced and purified as suggested by the manufacturer (Pharmacia). SDS-PAGE analysis and subsequent staining with Coomassie allowed the visualization of intact GST-ANTP proteins, which were $\geqslant 80 \%$ full-length. Drosophila casein kinase II was provided by C. Glover (University of Georgia, Athens). An in vitro kinase assay was performed as described (Glover et al. 1983) using $8 \mu \mathrm{g}$ of each GST-ANTP protein or $8 \mu \mathrm{g}$ of GST protein or casein. Sixty 
nanograms of CKII and $15 \mu \mathrm{C}$ of $\left[{ }^{32} \mathrm{P} \mid \gamma \mathrm{ATP}\right.$ at $3000 \mathrm{C} / \mathrm{mM}$ were included in each reaction. The products were separated by SDSPAGE and the gel was exposed to X-ray film for $<5 \mathrm{~min}$.

\section{EMSA}

EMSA were carried out as described (Chan et al. 1996). The EXD protein was nearly full-length (amino acids 1-323) and fused to a His tag in the $\mathrm{pQE}$ vector (Qiagen). All ANTP derivatives were nearly full-length (amino acid 10 to the carboxyl terminus) fused to the His tag in the $\mathrm{pQE}$ vector. Purification of these proteins from E. coli was as described by the manufacturer. The probe for Figure 8A was 5'-GGGGTGATTAATGGGCGCTG and for Figure $8 \mathrm{~B}, \mathrm{C}$ was $5^{\prime}$-GGGGTGATTTATGGGCGCTG (the ANTP and EXD-ANTP binding sites are underlined, respectively). The amounts of protein used in the binding reactions were normalized to the amount of full-length protein present in the preparation, as estimated by Coomassie staining of SDS-PAGE gels $(-35 \%$ to $\sim 75 \%)$. The concentrations used in Figure 8 were $\operatorname{ANTP}^{[1,2,3,4] \mathrm{A}}, 5.5 \mathrm{ng}(\mathrm{A}$, lane $1 ; \mathrm{C}$, lane 5$) ; 16.7 \mathrm{ng}$ $(A$, lane $2 ; C$, lanes 3,6); $50 \mathrm{ng}(\mathrm{A}$, lane 3; $\mathrm{C}$, lanes 4,7); ANTP, 5.5 ng $(\mathrm{A}$, lane $7 ; \mathrm{B}$, lane $10 ; \mathrm{C}$, lane 10$) ; 16.7 \mathrm{ng}(\mathrm{A}$, lane $8 ; \mathrm{B}$, lanes 8,11; C, lanes 8,11$) ; 50 \mathrm{ng}(\mathrm{A}$, lane 9; B, lanes 9,12; C, lanes 9,12); ANTP $^{(1,2,3,4) E}, 1.8 \mathrm{ng}(\mathrm{A}$, lane $4 ; \mathrm{B}$, lane 5$) ; 5.5 \mathrm{ng}(\mathrm{A}$, lane $5 ; \mathrm{B}$, lanes 3,6$) ; 16.7 \mathrm{ng}(\mathrm{A}$, lane 6; B, lanes 4,7); EXD, $100 \mathrm{ng}(\mathrm{B}$ and $\mathrm{C}$, lanes $2,5,6$, and $10-12$ ).

\section{Acknowledgments}

This work was primarily supported by grants from the March of Dimes Birth Defects Foundation awarded to R.S.M. L.J. was supported by a National Research Service Award from the National Institutes of Health (NIH) and H.-D.R. by an NIH grant awarded to R.S.M. We are indebted to P. Smith for injections, C. Glover for advice on CKII and for generously providing us with reagents, and $\mathrm{M}$. Abu-Shaar for the CKII in situ analysis. We are also very grateful to D. Brower, S. Celniker, S. Cohen, M. Hoffman, J. Jiang, F. Karch, W. McGinnis, M. Scott, B. Shilo, and G. Struhl for providing reagents. We also thank G. Campbell, F. Casares, S. Goff, I. Greenwald, S. Greenwood, G. Morata, B. Shilo, and G. Struhl for helpful discussions and/or comments on this manuscript.

The publication costs of this article were defrayed in part by payment of page charges. This article must therefore be hereby marked "advertisement" in accordance with 18 USC section 1734 solely to indicate this fact.

\section{References}

Berberich, S.J. and M.D. Cole. 1992. Casein kinase II inhibits the DNA-binding activity of Max homodimers but not Myc/ Max heterodimers. Genes \& Dev. 6: 166-176.

Bienz, M. 1994. Homeotic genes and positional signaling in the Drosophila viscera. Trends Genet. 10: 22-26.

Bier, E., L.Y. Jan, and Y.N. Jan. 1990. rhomboid, a gene required for dorsoventral axis establishment and peripheral nervous system development in Drosophila melanogaster. Genes \& Dev. 4: 190-203.

Botas, J. 1993. Control of morphogenesis and differentiation by HOM/Hox genes. Curr. Opin. Cell Biol. 5: 1015-1022.

Bourbon, J.-M., E. Martin-Blanco, D. Rosen, and T.B. Kornberg. 1995. Phosphorylation of the Drosophila engrailed protein at a site outside its homeodomain enhances DNA binding. $J$. Biol. Chem. 270: 11130-11139.
Burglin, T. 1994. A comprehensive classification of homeobox genes. In Guidebook to the homeobox genes /ed. D. Duboule), pp. 26-71. Oxford University Press, Oxford, UK.

Celniker, S.E., D.J. Keelan, and E.B. Lewis. 1989. The molecular genetics of the bithorax complex of Drosophila: Characterization of the products of the Abdominal-B domain. Genes \& Dev. 3: 1424-1436.

Chan, S.-K. and R.S. Mann. 1993. The segment identity functions of Ultrabithorax are contained within its homeo domain and carboxy-terminal sequences. Genes \& Dev. 7: 796811 .

Chan, S.-K., L. Jaffe, M. Capovilla, J. Botas, and R.S. Mann. 1994 The DNA binding specificity of Ultrabithorax is modulated by cooperative interactions with Extradenticle, another homeoprotein. Cell 78: 603-615.

Chan, S.-K., H. Pöpperl, R. Krumlauf, and R.S. Mann. 1996. An extradenticle-induced conformational change in a HOX protein overcomes an inhibitory function of the conserved hexapeptide motif. EMBO T. 15: 2477-2488.

Chien, C.-T., P. Bartel, R. Sternglanz, and S. Fields. 1991. The two-hybrid system: A method to identify and clone genes for proteins that interact with a protein of interest. Proc. Natl. Acad. Sci. 88: 9578-9582.

Chisaka, O., T.S. Musci, and M.R. Capecchi. 1992. Developmental defects of the ear, cranial nerves and hindbrain resulting from targeted disruption of the mouse homeobox gene Hox-1.6. Nature 355: 516-520.

Cohen, S.M., G. Bronner, F. Kuttner, G. Jürgens, and H. Jäckle. 1989. Distal-less encodes a homoeodomain protein required for limb development in Drosophila. Nature 338: 432-434.

Colberg-Poley, A.M., S.D. Voss, K. Chowdhury, C.L. Stewart, E.F. Wagner, and P. Gruss. 1985. Clustered homeo boxes are differentially expressed during murine development. Cell 43: $39-45$.

Cowley, S., H. Paterson, P. Kemp, and C.J. Marshall. 1994. Activation of MAP kinase is necessary and sufficient for PC12 differentiation and for transformation of NIH3T3 cells. Cell 77: 841-852.

Dalton, D., R. Chadwick, and W. McGinnis. 1989. Expression and embryonic function of empty spiracles: A Drosophila homeo box gene with two patterning functions on the anterior-posterior axis of the embryo. Genes \& Dev. 3: 19401956.

Desplan, C., J. Theis, and P.H. O'Farrell. 1985. The Drosophila developmental gene, engrailed, encodes a sequence-specific DNA binding activity. Nature 318: 630-635.

- 1988. The sequence specificity of homeodomain-DNA interaction. Cell 54: 1081-1090.

Duboule, D. 1991. Patterning in the vertebrate limb. Curr. Opin. Gen. Dev. 1: 211-216.

Durfee, T., K. Becherer, P.-L. Chen, S.-H. Yeh, Y. Yang, A.E. Kilburn, W.-H. Lee, and S.J. Elledge. 1993. The retinoblastoma protein associates with the protein phosphatase type I catalytic subunit. Genes \& Dev. 7: 555-569.

Ekker, S.C., D.G. Jackson, D.P. von Kessler, B.I. Sun, K.E. Young, and P.A. Beachy. 1994. The degree of variation in DNA sequence recognition among four Drosophila homeotic proteins. $E M B O$ I. 13: 3551-3560.

Frasch, M., T. Hoey, C. Rushlow, H. Doyle, and M. Levine. 1987. Characterization and localization of the even-skipped protein of Drosophila. EMBO J. 6: 749-759.

Freeman, M., C. Klambt, C.S. Goodman, and G.M. Rubin. 1992. The argos gene encodes a diffusible factor that regulates cell fate decisions in the Drosophila eye. Cell 69: 963-975.

Garcia-Bellido, A. 1975. Genetic control of wing disc development in Drosophila. In Cell patterning, Ciba Found. Symp. 
(ed. S. Brenner), pp. 161-182. Associated Scientific Publishers, New York, NY.

Gavis, E.R. and D.S. Hogness. 1991. Phosphorylation, expression and function of the Ultrabithorax protein family in Drosophila melanogaster. Devopment 112: 1077-1093.

Gibson, G. and W.J. Gehring. 1988. Head and thoracic transformation caused by ectopic expression of Antennapedia during Drosophila development. Development 102: 657-675.

Gibson, G., A. Schier, P. LeMotte, and W.J. Gehring. 1990. The specificities of Sex combs reduced and Antennapedia are defined by a distinct portion of each protein that includes the homeodomain. Cell 62: 1087-1103.

Glicksman, M.A. and D.L. Brower. 1988. Misregulation of homeotic gene expression in Drosophila larvae resulting from mutations at the extra sex combs locus. Dev. Biol. 126: 219-227.

Glover, C.V.C., E.R. Shelton, and D.L. Brutlag. 1983. Purification and characterization of a type II casein kinase from Drosophila melanogaster. J. Biol. Chem. 258: 3258-3265.

Gonzalez-Reyes, A. and G. Morata. 1990. The developmental effect of overexpressing a Ubx product in Drosophila embryos is dependent on its interactions with other homeotic products. Cell 61: 515-522.

Gonzalez-Reyes, A., N. Urquia, W.J. Gehring, G. Struhl, and G. Morata. 1990. Are cross-regulatory interactions between homoeotic genes functionally significant? Nature 344: 78-80.

Hanes, S.D. and R. Brent. 1989. DNA specificity of the bicoid activator protein is determined by homeodomain recognition helix residue 9. Cell 57: 1275-1283.

Hoey, T., R. Warrior, J. Manak, and M. Levine. 1988. DNAbinding activities of the Drosophila melanogaster evenskipped protein are mediated by its homeo domain and influenced by protein context. Mol. Cell. Biol. 8:-4598-4607.

Hupp, T.R., D.W. Meek, C.A. Midgley, and D.P. Lane. 1992. Regulation of the specific DNA binding function of p53. Cell 71: 875-886.

Ip, Y.T., R.E. Park, D. Kosman, E. Bier, and M. Levine. 1992. The dorsal gradient morphogen regulates stripes of rhomboid expression in the presumptive neuroectoderm of the Drosophila embryo. Genes \& Dev. 6: 1728-1739.

Jiang, J., D. Kosman, Y.T. Ip, and M. Levine. 1991. The dorsal morphogen gradient regulates the mesoderm determinant twist in early Drosophila embryos. Genes \& Dev. 5: 18811891.

Jones, B. and W. McGinnis. 1993. The regulation of empty spiracles by Abdominal-B mediates an abdominal segment identity function. Genes \& Dev. 7: 229-240.

Karch, F., W. Bender, and B. Weiffenbach. 1990. abdA expression in Drosophila embryos. Genes \& Dev. 4: 1573-1587.

Kenyon, C. and B. Wang. 1991. A cluster of Antennapedia-class homeobox genes in a nonsegmented animal. Science 253: 516-517.

Knighton, D.R., J. Zheng, L.F. Ten Eyck, V.A. Ashford, N.-H. Xuong, and J.M. Sowadski. 1991a. Crystal structure of the catalytic subunit of cyclic adenosine monophosphate-dependent protein kinase. Science 253: 407-414.

Knighton, D.R., J. Zheng, L.F. Ten Eyck, N.-H. Xuong, S. Taylor, and J.M. Sowadski. 1991b. Structure of a peptide inhibitor bound to the catalytic subunit of cyclic adenosine monophosphate-dependent protein kinase. Science 253: 414-420.

Lamka, M.L., A.M. Boulet, and S. Sakonju. 1992. Ectopic expression of UBX and ABD-B proteins during Drosophila embryogenesis: Competition, not a functional hierarchy, explains phenotypic suppression. Development 116: 841-854.

Lewis, E.B. 1978. A gene complex controlling segmentation in Drosophila. Nature 276: 565-570.
Lin, A., J. Frost, T. Deng, T. Smeal, N. Al-Alawi, U. Kikkawa, T. Hunter, D. Brenner, and M. Karin. 1992. Casein kinase II is a negative regulator of c-Jun DNA binding and AP-1 activity. Cell 70: 777-789.

Lin, L. and W. McGinnis. 1992. Mapping functional specificity in the Dfd and Ubx homeo domains. Genes \& Dev. 6: 10711081.

Lohs-Schardin, M., C. Cremer, and V.C. Nüsslein. 1979. A fate map for the larval epidermis of Drosophila melanogaster: Localized cuticle defects following irradiation of the blastoderm with an ultraviolet laser microbeam. Dev. Biol. 73: $239-255$

Lopez, A.J. and D.S. Hogness. 1991. Immunochemical dissection of the Ultrabithorax homeoprotein family in Drosophila melanogaster. Proc. Natl. Acad. Sci. 88: 9924-9928.

Luban, J., K.L. Bossolt, E.K. Franke, G.V. Kalpana, and S.P. Goff. 1993. Human immunodeficeincy virus type I Gag protein binds to cyclophilins A and Ab. Cell 73: 1067-1078.

Lufkin, T., M. Mark, C.P. Hart, P. Dolle, M. LeMeur, and P. Chambon. 1992. Homeotic transformation of the occipital bones of the skull by ectopic expression of a homeobox gene. Nature 359: 835-841.

Manak, J.R., N. de-Bisschop, R.M. Kris, and R. Prywes. 1990 Casein kinase II enhances the DNA binding activity of serum response factor. Genes \& Dev. 4: 955-967.

Mann, R.S. and S.-K. Chan. 1996. Extra specificity from extradenticle: The partnership between HOX and exd/pbx homeodomain proteins. Trends Genet. 12: 258-262.

Mann, R.S. and D.S. Hogness. 1990. Functional dissection of Ultrabithorax proteins in D. melanogaster. Cell 60: 597-610.

Marchiori, F., F. Meggio, O. Marin, G. Borin, A. Calderan, P. Ruzza, and L.A. Pinna. 1988. Synthetic peptide substrates for casein kinase 2. Assessment of minimum structural requirements for phosphorylation. Biochim. Biophys. Acta. 971: 332-338.

Mayer, U. and V.C. Nüsslein. 1988. A group of genes required for pattern formation in the ventral ectoderm of the Drosophila embryo. Genes \& Dev. 2: 1496-1511.

McCormick, A., N. Core, S. Kerridge, and M.P. Scott. 1995. Homeotic response elements are tightly linked to tissuespecific elements in a transcriptional enhancer of the teashirt gene. Development 121: 2799-2812.

Nilstad, P.R., A. Molven, J. Apold, and A. Fjose. 1990. The zebrafish homeobox gene hox-2.2: Transcription unit, potential regulatory regions and in situ localization of transcripts. EMBO I. 9: 515-524.

Padgett, R.W., D. St. Johnston, and W.M. Gelbart. 1987. A transcript from a Drosophila pattern gene predicts a protein homologous to the transforming growth factor-beta family. $\mathrm{Na}$ ture 325: 81-84.

Panganiban, G.E., R. Reuter, M.P. Scott, and F.M. Hoffmann. 1990. A Drosophila growth factor homolog, decapentaplegic, regulates homeotic gene expression within and across germ layers during midgut morphogenesis. Development 110: $1041-1050$

Papavassiliou, A.G., M. Treier, and D. Bohmann. 1995. Intramolecular signal transduction in cJUN. EMBO J. 14: 20142019.

Price, J.V., R.J. Clifford, and T. Schupbach. 1989. The maternal ventralizing locus torpedo is allelic to faint little ball, an embryonic lethal, and encodes the Drosophila EGF receptor homolog. Cell 56: 1085-1092.

Rauskolb, C. and E. Wieschaus. 1994. Coordinate regulation of downstream genes by extradenticle and the homeotic selector proteins. EMBO I. 13: 3561-3569.

Raz, E. and B.Z. Shilo. 1993. Establishment of ventral cell fates 
Jaffe et al.

in the Drosophila embryonic ectoderm requires DER, the EGF receptor homolog. Genes \& Dev. 7: 1937-1948.

Roder, L., C. Vola, and S. Kerridge. 1992. The role of the teashirt gene in trunk segmental identity in Drosophila. Development 115: 1017-1033.

Rutledge, B.J., K. Zhang, E. Bier, Y.N. Jan, and N. Perrimon. 1992. The Drosophila spitz gene encodes a putative EGF-like growth factor involved in dorsal-ventral axis formation and neurogenesis. Genes \& Dev. 6: 1503-1517.

Saxena, A., R. Padmanabha, and C.V. Glover. 1987. Isolation and sequencing of cDNA clones encoding alpha and beta subunits of Drosophila melanogaster casein kinase II. Mol. Cell. Biol. 7: 3409-3417.

Scheiter, E.D. and B.-Z. Shilo. 1989. The Drosophila EGF receptor homolog (DER) gene is allelic to faint little ball, a locus essential for embryonic development. Cell 56: 1093-1104.

Schiestle, R.H. and R.D. Geitz. 1989. High efficiency transformation of intact yeast cells using single stranded nucleic acids as a carrier. Curr. Genet. 16: 339-346.

Schneuwly, S., A. Kuriowa, P. Baumgartner, and W.J. Gehring. 1986. Structural organization and sequence of the homeotic gene Antennapedia of Drosophila melanogaster. EMBO $J$. 5: 733-739.

Schughart, K., M.F. Utset, A. Awgulewitsch, and F.H. Ruddle. 1988. Structure and expression of Hox-2.2, a murine homeobox-containing gene. Proc. Natl. Acad. Sci. 85: 55825586.

Schughart, K., D. Pravtcheva, M.S. Newman, L.W. Hunihan, Z. Jiang, and F.H. Ruddle. 1989. Isolation and regional localization of the murine homeobox-containing gene Hox-3.3 to mouse chromosome region 15E. Genomics 5: 76-83.

St. Johnston, D. and W.M. Gelbart. 1987. Decapentaplegic transcripts are localized along the dorsal-ventral axis of the Drosophila embryo. EMBO J. 6: 2785-2791.

Strathern, J.N. and D.R. Higgins. 1991. Recovery of plasmids from yeast into Escherichia coli: Shuttle vectors. In Guide to yeast genetics and molecular biology (ed. C. Guthrie and G.R. Fink), pp. 319-328. Academic Press, San Diego, CA.

Stroeher, V.L., E.M. Jorgensen, and R.L. Garber. 1986. Multiple transcripts from the Antennapedia gene of Drosophila melanogaster. Mol. Cell. Biol. 6: 4667-4675.

Sturtevant, M.A., M. Roark, and E. Bier. 1993. The Drosophila rhomboid gene mediates the localized formation of wing veins and interacts genetically with components of the EGF-R signaling pathway. Genes \& Dev. 7: 961-973.

Sunkel, C.E. and J.R.S. Whittle. 1987. Brista: A gene involved in the specification and differentiation of distal cephalic and thoracic structures in Drosophila melanogaster. Wilhelm Roux's Arch. Dev. Biol. 196: 124-132.

Taylor, S.S. and E. Radzio-Andzelm. 1994. Three protein kinase structures define a common motif. Structure 2: 345-355.

Treisman, J., P. Gonczy, M. Vashishtha, E. Harris, and C. Desplan. 1989. A single amino acid can determine the DNA binding specificity of homeodomain proteins. Cell 59: 553562.

Vachon, G., B. Cohen, C. Pfeifle, M.E. McGuffin, J. Botas, and S. Cohen. 1992. Homeotic genes of the Bithorax complex repress limb development in the abdomen of the Drosophila embryo through the target gene Distal-less. Cell 71: 437450.

Wedden, S.E., K. Pang, and G. Eichele. 1989. Expression pattern of homeobox-containing genes during chick embryogenesis. Development 105: 639-650.

White, R.A.H. and M. Wilcox. 1985. Distribution of Ultrabithorax proteins in Drosophila. EMBO J. 4: 2035-2043.

Wieschaus, E. and C. Nüsslein-Volhard. 1986. Looking at em- bryos. In Drosophila, A practical approach (ed. D.B. Roberts|, pp. 199-228. IRL Press Limited, Oxford, UK.

Wright, C.V., K.W. Cho, A. Fritz, T.R. Burglin, and R.E. De. 1987. A Xenopus laevis gene encodes both homeoboxcontaining and homeobox-less transcripts. EMBO J. 6: 4083-4094.

Zak, N.B. and B.Z. Shilo. 1992. Localization of DER and the pattern of cell divisions in wild-type and Ellipse eye imaginal discs. Dev. Biol. 149: 448-456.

Zeng, W., D.J. Andrew, L.D. Mathies, M.A. Horner, and M.P. Scott. 1993. Ectopic expression and function of the Antp and Scr homeotic genes: The $\mathrm{N}$ terminus of the homeodomain is critical to functional specificity. Development 118: 339-352. 


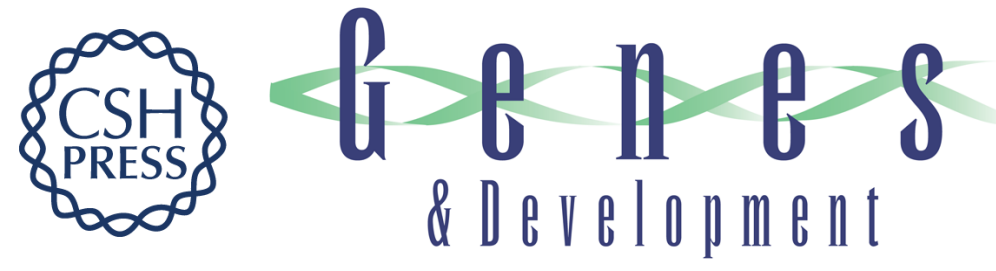

\section{A role for phosphorylation by casein kinase II in modulating Antennapedia activity in Drosophila.}

L Jaffe, H D Ryoo and R S Mann

Genes Dev. 1997, 11:

Access the most recent version at doi:10.1101/gad.11.10.1327

References This article cites 80 articles, 34 of which can be accessed free at:

http://genesdev.cshlp.org/content/11/10/1327.full.html\#ref-list-1

License

Email Alerting

Service

Receive free email alerts when new articles cite this article - sign up in the box at the top right corner of the article or click here.

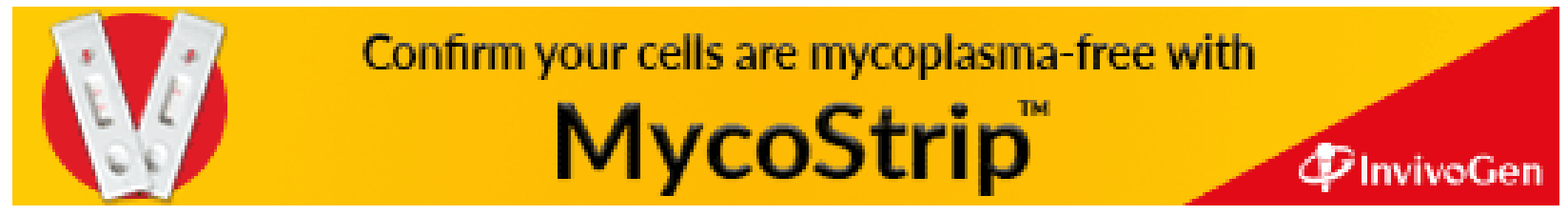

